\title{
Functional Expression of Microsomal and Mitochondrial Cytochrome P-450 (d and SCC) in COS-7 Cells from Cloned cDNA
}

\author{
Osamu Minowa ${ }^{1,2}$, Kazuhiro Sogawa ${ }^{1,3}$, Yujiro Higashi ${ }^{1}$ and Yoshiaki Fujii-Kuriyama $^{1,3 *}$ \\ ${ }^{1}$ Department of Biochemistry, Cancer Institute, Japanese Foundation for Cancer Research, Toshima-ku, \\ Tokyo 170; ${ }^{2}$ Section of Biochemistry, Institute of Immunological Science, Hokkaido University, Kita-ku, \\ Sapporo, Hokkaido 060; and ${ }^{*}$ Department of Chemistry, Faculty of Science, Tohoku Univlersity, Sendai, \\ Miyagi 980, Japan
}

Key words: Monooxygenase/cDNA expression/COS-7 cells/P-450d/P-450 SCS

\begin{abstract}
$A B S T R A C T$. Using full length cDNA introduced into COS-7 cells, two species of $\mathbf{P}-\mathbf{4 5 0}$ with entirely different physiological functions have been expressed in enzymatically active form. One is P-450d, which is known to reside in the microsomes of rat hepatocytes where it acts as a drug-metabolizing enzyme; the other is $P$ 450(SCC), which catalyzes the conversion of cholesterol to pregnenolone in the rate-limiting reaction of steroidogenesis in mitochondria of adrenal cortex cells. Northern blot and immunoblot analyses revealed that the mRNA and protein of these $\mathrm{P}-450$ species were efficiently produced in COS-7 cells. The protein contents amounted to nearly $0.1 \%$ of the total cell protein as estimated from immunoblotting and low temperature $\mathrm{CO}$ difference spectra. The subcellular localization of the products indicated that they were correctly sorted to the microsomes and mitochondria, respectively. We have succeeded in eliciting most of the activity of the expressed microsomal P-450d by reconstruction with NADPH-cytochrome $P-450$ reductase, while the optimal conditions for the mitochondrial enzyme in the COS cells remain to be studied.

These results show the applicability of the COS-7 expression system to investigations of the functions of members of the P-450 superfamily whose cDNA has been newly isolated.
\end{abstract}

Cytochrome P-450 constitutes a superfamily of hemoproteins which are believed to have evolved from a common ancestor. They catalyze the monooxygenase reaction of xenobiotics, such as drugs, carcinogens and environmental pollutants, as well as endobiotics, such as steroids, fatty acids, and prostaglandins $(1,2)$. This versatility of the enzyme system is probably due to the large number of $\mathrm{P}-450$ species and their different and sometimes broad substrate specificities. The multiple molecular forms of $\mathrm{P}-450$ have several properties in common, such as size, structure, and immunologic and biochemical characteristics, which makers it difficult to separate one form from another biochemically. Recent application of molecular cloning technology to the field of P-450 has overcome this difficulty and brought about clear-cut identification of many forms of P-450 $(2,3)$. However, there seem to remain a considerable number of uncharacterized P-450 species, especially the minor forms in higher organisms. When a cDNA clone for a certain species of $\mathrm{P}-450$ whose function is not known is isolated by cross-hydridization with the cDNA of a

\footnotetext{
* To whom correspondence and reprint requests should be addressed.
}

known $\mathrm{P}-450$, it is prerequisite for characterization of the new species to establish a suitable expression system for the cDNA information. The expression system may also be helpful for investigating the structure-function relationship in P-450 molecules by site-directed mutagenesis and for analyzing causative mutations in defective genes of genetic deseases related to the $P-450$ superfamily.

In the present study we attempted to express two P450 species [P-450d and $\mathrm{P}-450(\mathrm{SCC})]$ with different functions and localizations in the monkey kidney cell line COS-7 by transfection with on expression vector (pKCR) carrying their cDNA sequences. The P-450 molecules expressed in COS cells exhibited their correct cellular localizations and functional activities, although their activities seemed suboptimal. Our laboratory has reported a successful application of this system to the analysis of defective genes in congenital P-450c21 deficiency (4).

\section{MATERIALS AND METHODS}

Enzymes and chemicals. Restriction endonucleases, DNA polymerase (Klenow fragment), T4 DNA ligase, and bacterial 
alkaline phosphatase were purchased from Takara Shuzo Co. (Kyoto, Japan). Proteinase $\mathrm{K}$ was obtained from BoeringerMannheim (Penzberg, West Germany). Trypsin, glucose-6phosphate, and glucose-6-phosphate dehydrogenase were obtained from Sigma (St. Louis, MO, U.S.A.). NADPH was obtained from Oriental Kobo Co. (Tokyo, Japan). [a- $\left.{ }^{32} \mathrm{P}\right]-$ dCTP (2000-3000 Ci/mmol) was obtained from The Radiochemical Center (Amersham, England); $\left[2-{ }^{3} \mathrm{H}\right]$-estradiol-17 $(25.3 \mathrm{Ci} / \mathrm{mmol})$, and $\left[7-{ }^{3} \mathrm{H}\right]$-pregnenolone $(22.6 \mathrm{Ci} / \mathrm{mmol})$ were from INEN Research Products (Boston, MA, U.S.A.).

Construction of plasmids. Yeast expression vectors containing P-450d or SCC cDNA were kindly supplied by Dr. T. Shimizu (Tohoku University). A cDNA insert of P-450d was obtained by Hin dIII digestion of pAAH5 P-450d, and that of P-450(SCC) was by Eco RI digestion of YEp1PT P-450(SCC) (5). The expression vector $\mathrm{pKCRH} 2$ for COS cells was kindly supplied by Drs. M. Mishina and S. Numa (Kyoto University) (6). The P-450d cDNA insert was ligated to the unique Hin dIII site of pKCRH2. Prior to ligation of the P-450(SCC) cDNA insert to the Eco RI site just flanking the Hin dIII site, another Eco RI site of pKCRH2 located to the 5'-terminal side of the SV40 promoter region was disrupted by partial digestion with Eco RI; the sticky ends were filled with the Klenow fragment, and the resultant blunt ends were ligated.

Transfection of COS cells. COS-7 cells were a kind gift from Dr. Y. Gluzman (7). Introduction of pKCRP-450 expression plasmids into COS-7 cells was by the calcium phosphate method as previously described (8). The efficiency of transfection by the method was greater than by the DEAE-dextran method under our conditions as judged from the amounts of mRNA expressed.

The night before transfection, COS-7 cells were passaged from a confluent 100-mm culture dish (Corning 2520) by trypsinization. Transfection was performed $4 \mathrm{~h}$ after the medium was replaced by $5 \mathrm{ml}$ of the fresh one. Calcium phosphateDNA precipitates were developed for $10 \mathrm{~min}$ on ice from a $15-$ $\mu \mathrm{g}$ aliquot of DNA per dish in $400 \mu \mathrm{l}$ of $50 \mathrm{mM}$ Hepes buffer (pH 7.10) containing $280 \mathrm{mM} \mathrm{NaCl}, 1.5 \mathrm{mM} \mathrm{Na} \mathrm{HPO}_{4}$, and $120 \mathrm{mM} \mathrm{CaCl}_{2}$. The precipitates were added to culture dishes and incubated at $37^{\circ} \mathrm{C}$ for $4 \mathrm{~h}$ with $100 \mu \mathrm{g} / \mathrm{ml}$ of chloroquine (9). The cells were then treated with $20 \%$ glycerol (8). After the transfection, they were incubated at $37^{\circ} \mathrm{C}$ for $48 \mathrm{~h}$, and then the medium was exchanged with the fresh one to facilitate cell growth.

RNA blot hybridization analysis. Total RNA was extracted from transfected COS-7 cells by the guanidine thiocyanate method of Chirgwin, et al. (10). The total RNA $(5 \mu \mathrm{g})$ was denatured for electrophoresis on a $0.8 \%$ agarose gel containing $2.2 \mathrm{M}$ formaldehyde, and then transferred to a nitrocellulose filter. It was then hybridized with either ${ }^{32} \mathrm{P}$-labeled P-450d or P-455(SCC) cDNA insert $\left(1 \times 10^{8} \mathrm{cpm} / \mu \mathrm{g}\right)$. Ribosomal RNAs stained with ethidium bromide were used as size markers.

Immunoblotting for protein analysis. The IgG fraction $\left(\mathrm{AP}_{1} \mathrm{G}, 5.3 \mathrm{mg} / \mathrm{ml}\right)$ of rabbit antiserum raised against $\mathrm{P}-450 \mathrm{c}$
(11), which equally recognizes P-450d, was a kind gift from Dr. Kawajiri (Saitama Cancer Center Research Institute). Rabbit antiserum against P-450(SCC) was kindly supplied by Dr. T. Omura (Kyushu University) and fractionated on DEAE-cellulose to obtain the $\mathrm{IgG}$ fraction $(75 \mathrm{mg} / \mathrm{ml})$.

Transfected cells were harvested from a dish and boiled for $3 \mathrm{~min}$ in $270 \mu \mathrm{l}$ of SDS sampling solution [10 mM Tris- $\mathrm{HCl}$ (pH 7.5), 1 mM EDTA, 1\% SDS, 5\% mercaptoethanol]. Protein concentrations of cell lysates were determined by the CBB method (12) at about $10^{3}$-fold dilution to eliminate interference in the colorimetry by SDS. Twenty $\mu \mathrm{g}$ of protein of each of the whole cell lysates and subcellular components were subjected to slab SDS-PAGE after Laemmli (13), and the resolved proteins were electroblotted in transfer buffer $(20 \mathrm{mM}$ Tris, $0.121 \mathrm{M}$ glycine, $20 \%$ ethanol) onto a nitrocellulose filter. The protein-transferred filter was blocked in a $1: 4$ mixture of FCS and PBS-TX100-BSA solution [10 mM sodium phosphate ( $\mathrm{pH} 7.5), 0.15 \mathrm{M} \mathrm{NaCl}, 0.05 \%$ Triton $\mathrm{X}-100,5 \% \mathrm{BSA})$ at room temperature for $1 \mathrm{~h}$. Then the filter was incubated at room temperature for $1 \mathrm{~h}$ with the first antibody solution, containing anti-P-450c IgG or anti-P-450(SCC) IgG. The second antibody solution [consisting of $0.05 \mathrm{mg} / \mathrm{ml}$ peroxidase-conjugated goat anti-rabbit IgG (CAPPEL) in PBS-TX100-BSA] was applied to the filter, and it was incubated at room temperature for $1 \mathrm{~h}$. The immunoreactive bands on the filter were stained by incubation in $50 \mathrm{mM}$ Tris- $\mathrm{HCl}(\mathrm{pH} 7.5), 0.4 \mathrm{mg} / \mathrm{ml}$ 4-chloro-1-naphthol, and $0.01 \% \mathrm{H}_{2} \mathrm{O}_{2}$. During each interval of the incubation, the filter was washed three times in PBSTX100.

In order to quantitate the intensity of the immuno-stained bands, the stained filter itself or the photograph of the filter was subjected to reflectometry with a Shimizu CS-910. Known amounts of purified P-450d (14) and P-450(SCC) (15) were used as standards.

Fractionation of subcellular components. COS cells harvested from 4 dishes ( $4.8 \mathrm{mg}$ protein) were homogenized by brief ultrasonication in $6 \mathrm{ml}$ of $0.25 \mathrm{M}$ sucrose solution containing $5 \mathrm{mM}$ Mops- $\mathrm{NaOH}(\mathrm{pH} 7.5), 1 \mathrm{mM}$ EDTA, $10 \mu \mathrm{g} / \mu \mathrm{l}$ of pepstatin $\mathrm{A}$, and $10 \mu \mathrm{g} / \mu \mathrm{l}$ of leupeptin. The homogenate was centrifuged differentially (16) to obtain subcellular fractions: P0.7 ("nuclei": $0.7 \mathrm{k} \mathrm{G}, 10 \mathrm{~min}$ ), P8 ("mitochondria": $8 \mathrm{k} \mathrm{G}, 10 \mathrm{~min}$ ), P120 ("microsomes": $120 \mathrm{k} \mathrm{G}, 60 \mathrm{~min}$ ), and S120 supernatant ("cytosol": $120 \mathrm{k} \mathrm{G}, 60 \mathrm{~min}$ ).

Succinate-cytochrome c oxidoreductase (SCOR) activity was measured as a marker of mitochondria (17). The reaction mixtures $(2.0 \mathrm{ml})$ contained $50 \mathrm{mM}$ potassium phosphate (pH 7.4), $1 \mathrm{mM} \mathrm{KCN}, 20 \mathrm{mM}$ sodium succinate, $25 \mu \mathrm{M}$ cytochrome $\mathrm{c}$, and a suspension of one of the subcellular fractions (1/4 portion of each pellet from cells of 4 dishes). The time course of absorbance at $550 \mathrm{~nm}$ was measured and the initial velocity was calculated. As a marker enzyme of microsomes, glucose-6-phosphatase activity was measured (18) in the reaction mixture $(0.5 \mathrm{ml})$ containing $40 \mathrm{mM}$ glucose-6-phosphate, $50 \mathrm{mM}$ Tris-Malate [pH 6.8], and one of the subcellular fractions ( $1 / 3$ portion of each fraction). Each mixture was incu- 
bated at $30^{\circ} \mathrm{C}$ for $30 \mathrm{~min}$; then the reaction was stopped by addition of TCA solution. Liberated phosphate was determined by the method of Fiske and SubbaRow (19).

Subcellular fractions from COS cells were digested with proteinase $\mathrm{K}$ as descibed $(20)$.

Low temperature CO-reduced difference spectrum. The mitochondrial and microsomal fractions [P8 and P120 suspended in 0.25 M sucrose, $5 \mathrm{mM}$ Mops- $\mathrm{NaOH}$ ( $\mathrm{pH} 7.5$ ), 3 $4 \mu \mathrm{g} / \mu \mathrm{l}$ of protein] from COS-7 cells were reduced with an excess amount of dithionite (21). One-half of the fraction was then saturated with carbon monoxide. Fifty $\mu$ l of $60 \%$ glycerol in PBS was added to 50- $\mu \mathrm{l}$ aliquots of CO-saturated and non-treated fractions, respectively. Co difference spectra were recorded with a High-Sensitivity Spectrometer (Union Giken Co.) in which a liquid $\mathrm{N}_{2}$ Dewar bottle with quartz glass windows for the light path was settled $(22,23)$. P-450cam was used as the standard for estimation of the chromophore concentrations in the sample solution.

Reconstruction of microsomal P-450d with exogenous $N A D P H$-cytochrome $P-450$ reductase. Purified $\mathrm{P}-450$ reductase (Fp) (24) was a generous gift from Dr. T. Iyanagi (Tsukuba University). The amount of Fp was determined by measurement of absorbance at $450 \mathrm{~nm}$ using the molar absorbance coefficient of $1 \times 10^{5} \mathrm{~cm}^{-1} \mathrm{M}^{-1}$.

The reconstruction was performed essentially according to the procedure by Miwa and Lu (25). Sodium cholate (1.2 $\mathrm{mg}$ ) was added to the microsomal fractions (P120) (440 $\mu \mathrm{g}$ of protein), and the solution were subjected to brief sonication. Then 440 pmol of $F p$ was added to these fractions. This amount corresponds roughly to a $1: 10$ molar ratio relative to the amount of $\mathrm{P}-450 \mathrm{~d}$ in each fraction, estimated from the low temperature CO-reduced difference spectra. The volumes of these fractions were then adjusted to about $270 \mu 1$ by addi-

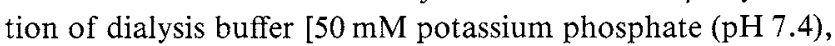
$0.1 \mathrm{mM}$ EDTA, $0.1 \mathrm{mM}$ DTT]. Finally, to equilibrate the system, they were dialyzed three times at $4^{\circ} \mathrm{C}$ for $12 \mathrm{~h}$ against 6 liters of the dialysis buffer. The dialyzed microsomal fractions were subjected to the activity measurements. The above procedure was essential for efficient reconstruction of P-450d and exogenous $\mathrm{Fp}$, as indicated in Results.

Assay of expressed P-450 activities. Expressed P-450d monoxygenase activity was assayed with estradiol as a substrate (26). The reaction mixture $(500 \mu \mathrm{l})$ contained $5 \mathrm{nmol}$ or $100 \mathrm{nmol}$ of $\left[2-{ }^{3} \mathrm{H}\right]$-estradiol $-17(0.5 \mu \mathrm{Ci}), 3 \mathrm{mM}$ NADPH, $40 \mathrm{mM}$ glucose-6-phosphate, 1 unit of glucose-6-phosphate dehydrogenase, $70 \mathrm{mM}$ potassium phosphate $(\mathrm{pH} 7.4)$, and the microsomal fraction ( $440 \mu \mathrm{g}$ of protein). The mixture was incubated at $37^{\circ} \mathrm{C}$ for $60 \mathrm{~min}$, and the reaction was stopped by addition of $1 \mathrm{ml}$ of $1.5 \mathrm{~N} \mathrm{HCl}$. After centrifugation $(3 \mathrm{k} \mathrm{rpm}$, $20 \mathrm{~min}$ ), the supernatant of the reaction mixture was applied to a Pasteur-pipette column packed with about $3 \mathrm{ml}$ of XAD2 resin equilibrated with $\mathrm{H}_{2} \mathrm{O}$. The column was wahsed first with $7 \mathrm{ml}$ of $\mathrm{H}_{2} \mathrm{O}$ and then with $8 \mathrm{ml}$ of methanol. The estradiol 2-hydroxylation reaction was accompanied by formation of ${ }^{3} \mathrm{H}_{2} \mathrm{O}$ which was eluted first with $\mathrm{H}_{2} \mathrm{O}$, while the unre- acted labeled estradiol was later eluted with methanol. The radioactivity of tritium in the collected $\mathrm{H}_{2} \mathrm{O}$ fractions, methanol fractions, and $1.5 \mathrm{~N} \mathrm{HCl}$ precipitate was measured with a liquid sintilation counter LS-3801 for calculation of the substrate conversion ratio.

P-450(SCC) enzyme activity was detected by measurement of pregnenolone released into the culture medium of the COS cells transfected with the $\mathrm{P}-450$ (SCC) expression vector. RIA was performed for determination of the pmol level of pregnenolone as described previously (27). On the fourth day after transfection, $20 \mathrm{nmol}$ of 25 -hydroxycholesterol was added to $10 \mathrm{ml}$ of medium in a culture dish, and the cells were incubated for another 24 or 120 . One milliliter of this medium was left standing at room temperature for $30 \mathrm{~min}$ in order to equilibrate with $\left[7-{ }^{3} \mathrm{H}\right]$-pregnenolone $(3000 \mathrm{cpm})$ which served as an internal standard for recovery calculation. It was then extracted with $10 \mathrm{ml}$ of methylene chloride. The organic phase was evaporated by passing $\mathrm{N}_{2}$ over it and dissolved in $100 \mu \mathrm{l}$ of HPLC solvent ( $4 \%$ isopropanol/hexane). The wall of the plastic tube used for evaporation was rinsed with another $100 \mu \mathrm{l}$ of the same solvent; the combined $200 \mu \mathrm{l}$ was dried again and re-dissolved in $50 \mu \mathrm{l}$ of the solvent. It was then subjected to HPLC on a silica- 60 column and eluted with the same solvent. The radioactive fractions were collected and dried. This purification procedure was essential to eliminate cross-reaction of the pregnenolone-antiserum with $25-\mathrm{OH}-$ cholesterol which might have been in the extract solution.

The obtained residues were dissolved in $700 \mu 1$ of RIA assay buffer consisting of $0.1 \mathrm{M}$ sodium phosphate $(\mathrm{pH} 7.0), 0.9 \%$ $\mathrm{NaCl}, 0.1 \%$ sodium azide, and $1 \mathrm{mg} / \mathrm{ml}$ egg albumin. The solution was left standing for at least $1 \mathrm{~h}$ at room temperature to improve solubility. The tritium radioactivity in $200 \mu \mathrm{l}$ of this purified-extract solution was counted for estimation of the recovery, and the remaining $500 \mu \mathrm{l}$ was applied to RIA using sheep antiserum SLB SE-0000-53 against pregnenolone ( $1 / 1000$ dilution with the assay buffer). One hundred $\mu \mathrm{l}$ of the diluted serum and $100 \mu \mathrm{l}$ of $\left[7-{ }^{3} \mathrm{H}\right]$-pregnenolone $\left(3 \times 10^{4}\right.$ $\mathrm{dpm}$ ) dissolved in the assay buffer were added to the $500 \mu \mathrm{l}$ of HPLC-purified extract solution and the mixture was left standing at $4{ }^{\circ} \mathrm{C}$ overnight. Then free pregnenolone was removed by addition of $200 \mu \mathrm{l}$ of charcoal-dextran solution $(0.625 \%$ Norit A, $0.0625 \%$ dextran). After incubation at $4^{\circ} \mathrm{C}$ for $20 \mathrm{~min}$, the mixture was centrifuged $(5 \mathrm{k} \mathrm{rpm}, 2 \mathrm{~min})$, and the tritium radioactivity in the supernatant was counted. A standard measurement was performed in exactly the same way using known amounts of cold pregnenolone.

\section{RESULTS}

The transient expression system mediated by the plasmid DNAs possesses the advantages of efficiency of transfection and freedom from possible effects of the integration site in the genomic sequence (28). In COS cells, the pKCR-expression plasmid insures abundant transcription (6) (Fig. 1a). Marked hybridization signals 
could be seen 2 days after transfection. Co-transfection of P-450d and P-450(SCC) cDNA into COS-7 cells led to production of the respective mRNAs with almost equal efficiency. Both the cDNAs gave a single band of mRNAs at $19.5 \mathrm{~S}$, which is consistent with their full lengths.

The left half of Fig. 1b shows the bands of the P-450d protein stained with $\mathrm{P}-450 \mathrm{c}$ antibody which is cross-reactive to P-450d (11). The mixture ( $1: 2$ by weight) of standard P-450d and P-450d from transfected cells gave a single band, indicating that the transfected cells produced an immunoreactive protein which is electrophoretically indistinguishable from authentic P-450d. The amount of expressed P-450d in the cell was estimated from the band intensity to be $0.1 \%$ of the total cell proteins ( $20 \mathrm{pmol} \mathrm{P} 450 \mathrm{~d} / \mathrm{mg}$ cell protein) 3 days after trans- fection.

On the other hand, the P-450(SCC)-cDNA transfected cells produced two immunoreactive bands against anti-P-450(SCC) antibody, (the right half of Fig. 1b). Since the P-450(SCC) cDNA contained the full-length sequence coding for the P-450(SCC) precursor, we assume that the larger band corresponds to $\mathrm{P}$ 450 (SCC) precursor and the smaller to the mature form. This figure also indicates that a mixture of standard $\mathrm{P}-450$ (SCC) purified from bovine adrenal cortex and $\mathrm{P}-450$ (SCC) from the transfected cells [P-450(SCC) $\mathrm{Mt}$ ] gave two bands, of which the smaller one contained $\mathrm{P}-450$ (SCC) proteins from the two origins, showing that the smaller protein expressed by the COS cells had the same molecular weight as the authentic mature form. The amount of the product was approximately
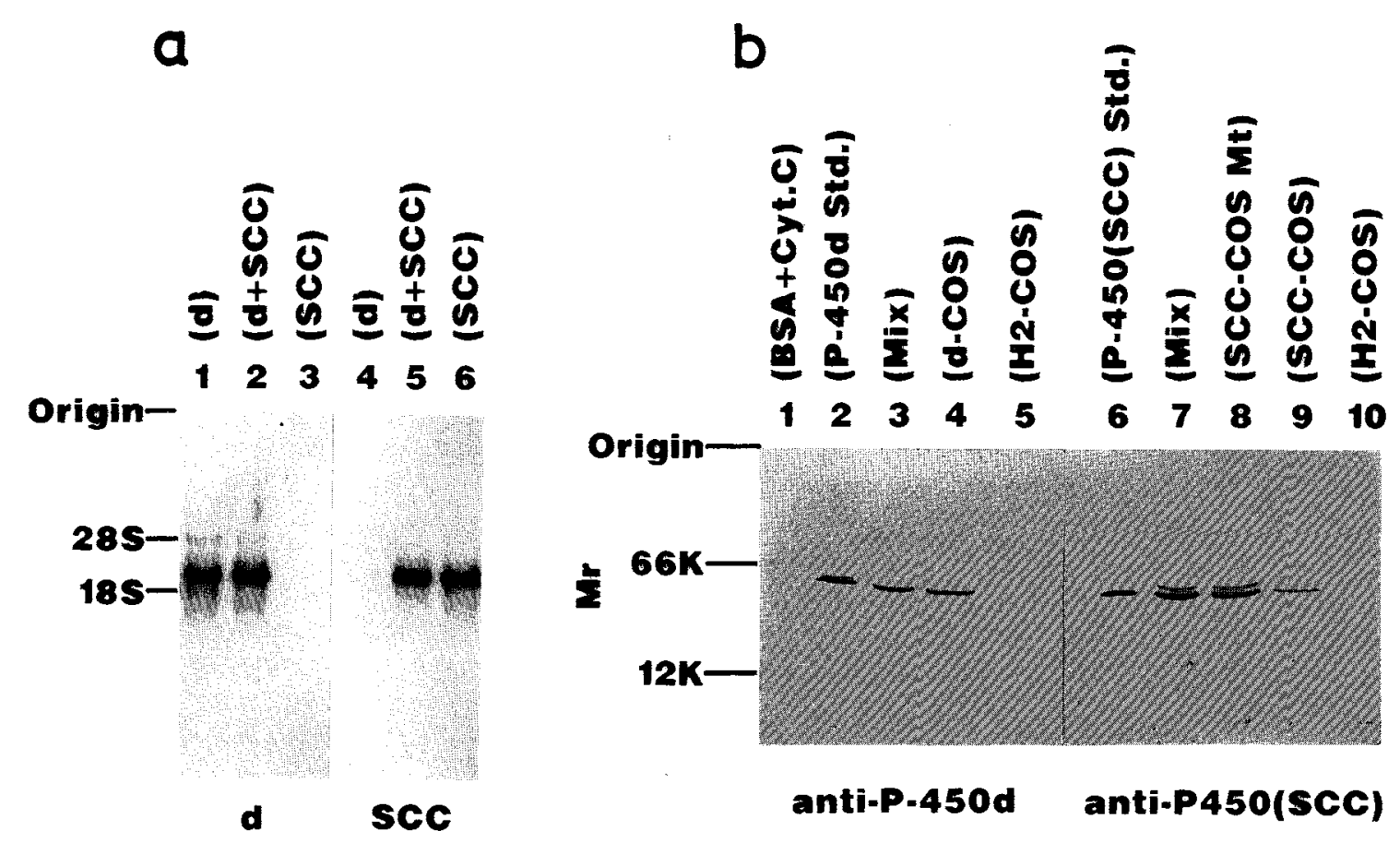

\section{Probe}

Fig. 1. Expression of mRNA and protein from cDNA of P-450d and P-450 (SCC). a. mRNA-blot hybridization analysis of transfected COS-7 cells. Cells were harvested 2 days after transfection and $5 \mu \mathrm{g}$ of extracted total RNA was analyzed. Lanes 1 and 4 (d), total RNA from cells transfected with pKCRP-450d $(15 \mu \mathrm{g})$; lanes 2 and $5(\mathrm{~d}+\mathrm{SCC})$, pKCRP-450d $(15 \mu \mathrm{g})$ plus pKCRP-450 (SCC) (15 $\mu \mathrm{g}) ;$ lanes 3 and 6 (SCC), P-450 (SCC) $(15 \mu \mathrm{g})$. The nitrocellulose filter of lanes $1-3$ was hybridized with nick-translated P-450d cDNA and the filter of lanes 4-6 with P-450 (SCC) CDNA. The hybridized filters were washed, then exposed to Fuji-RX film for $2 \mathrm{~h}$ at $-80^{\circ} \mathrm{C}$. The positions of RNA markers are shown to the left of the autoradiogram. b. Immunoblot analysis of expressed P-450d and P-450 (SCC) in COS-7 cells. Lane 1 (BSA + cyt. c), bovine serum albumin $(2 \mu \mathrm{g})$ and cytochrome c $(2 \mu \mathrm{g})$ as molecular weight markers; lane 2 (P-450d std.), purified P-450d (10 ng); lane 4 (d-COS), whole cell lysate $(20 \mu \mathrm{g})$ of cells transfected with pKCRP-450d; lane 3 (Mix), a mixture of purified P-450d $(5 \mathrm{ng})$ and d-COS $(10 \mu \mathrm{g})$; lanes 5 and 10 (H2$\mathrm{COS}$ ), whole cell lysate $(20 \mu \mathrm{g})$ transfected with pKCRH2; lane 6 [P-450 (SCC) std.], purified bovine P-450 (SCC) (40 ng); lane 8 (SCC-COS Mt), mitochondrial fraction $(20 \mu \mathrm{g})$ from cells transfected with pKCRP-450 (SCC); lane 7 (Mix), a mixture of purified P-450 (SCC) (20 ng) and SCCCOS Mt $(10 \mu \mathrm{g})$; lane 9 (SCC-COS), whole cell lysate $(20 \mu \mathrm{g})$ transfected with pKCRP-450 (SCC). Protein-blotted filters of lanes $1-5$ were incubated with anti-P-450 antibody, followed by incubation with peroxidase-conjugated goat anti-rabbit IgG and with 4-Cl-1-naphtol solution. The notation "anti-P-450c" at the bottom of the filter represents only its reactivity. In lane 2 , the faint band just above the dense band of P-450d indicates contamination with P-450c. The filter of lanes 6-10 was incubated with anti-P-450 (SCC) antibody and treated in the same way. 
$0.2 \%$ of the total mitochondrial protein $(40 \mathrm{pmol} / \mathrm{mg})$ when harvested 3 days after transfection. The band intensity of mitochondria of the plasmid-transfected COS cells was higher than that of the whole-cell lysate, indicating the mitochondrial localization of the product.

As shown in Fig. 2, the maximum amount of the mRNA for P-450d was achieved on the third day after transfection. P-450d protein also increased similarly to reach a maximum on the third or fourth day after transfection. Most of the mRNA disappeared after 1 week, whereas the cells at this time still retained half or more of the maximal level of P-450d protein.

The concentration of mRNA for P-450(SCC) could be equal to that of P-450d, as deduced from Fig. 1a. The amount of $\mathrm{P}-450(\mathrm{SCC})$ protein expressed from its vector reached a maximum value on the fourth or fifth day as indicated by the immuno-stained filter of Fig. 2; this corresponded to about $0.1 \%$ of the whole cell protein. Similar to the case with P-450d, more than half of the maximal concentration remained after 1 week; this disappeared 2 weeks later.

The intracellular distribution of expressed P-450d and $\mathrm{P}-450(\mathrm{SCC})$ was examined by fractionating the components of transfected COS cells. As shown in Fig. 3 , the distribution of P-450d protein was consistent with that of a microsome marker enzyme (G-6-Pase), while the distribution of the P-450(SCC) mature form was consistent with that of a mitochondrial marker enzyme (SCOR). The mitochondrial localization of the mature form was demonstrated more clearly when each fraction was treated with proteinase $\mathrm{K}$, which selectively digests the precursor form. The resistance of the mature form suggests that it was localized on the matrix-side surface of the inner mitochondrial membranes. The precursor form, on the other hand, appeared to reside on the outer surface of all membranous fractions (P0.7, P8, and P120), and was thus sensitive to the proteolytic digestion.

The content of the expressed P-450d in microsomes was also determined from the $\mathrm{CO}$ difference spectra at liquid nitrogen temperature. The molar extinction coeffcient at $448 \mathrm{~nm}$ for the protoheme of P-450 was estimated from the known amount of P-450cam to be $1.88 \times 10^{3} \mathrm{mM}^{-1} \mathrm{~cm}^{-1}$, about 20 fold higher than at room temperature.

The spectrum in Fig. 4 clearly shows a positive peak
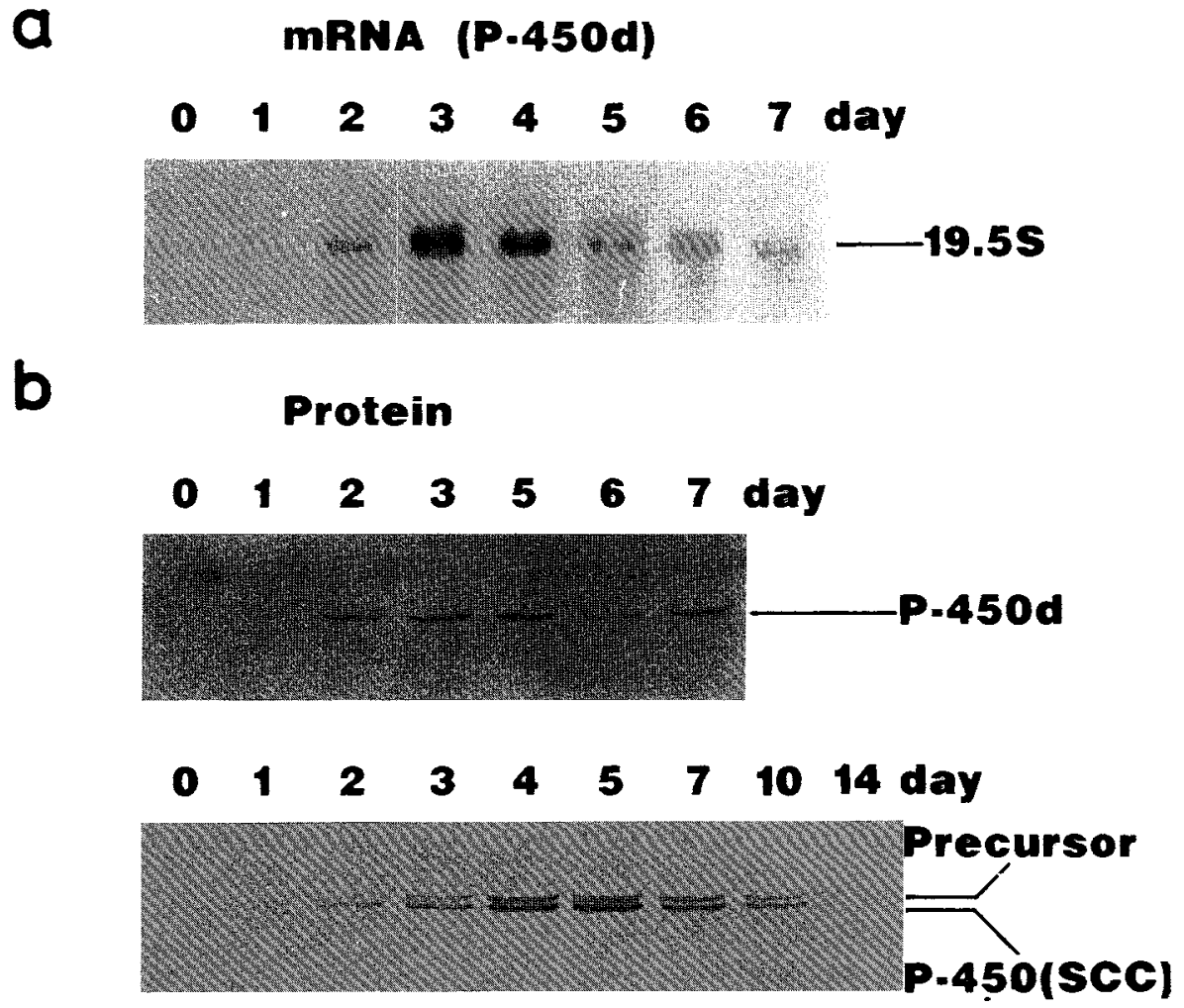

Fig. 2. Time course of P-450 expression. a. Total RNA ( $5 \mu \mathrm{g}$ ) extracted from COS-7 cells on the day indicated after transfection were electrophoresed, blotted to a nitrocellulose filter, and hybridized with ${ }^{32} \mathrm{P}$-labeled P-450d cDNA. b. Immunoblot analysis was performed as described in Methods for each of the total cell lysates $(20 \mu \mathrm{g})$. The cells were harvested on the day indicated after transfection with pKCRP-450d (upper filter), or pKCRP-450 (SCC) (lower filter). 


\section{a}

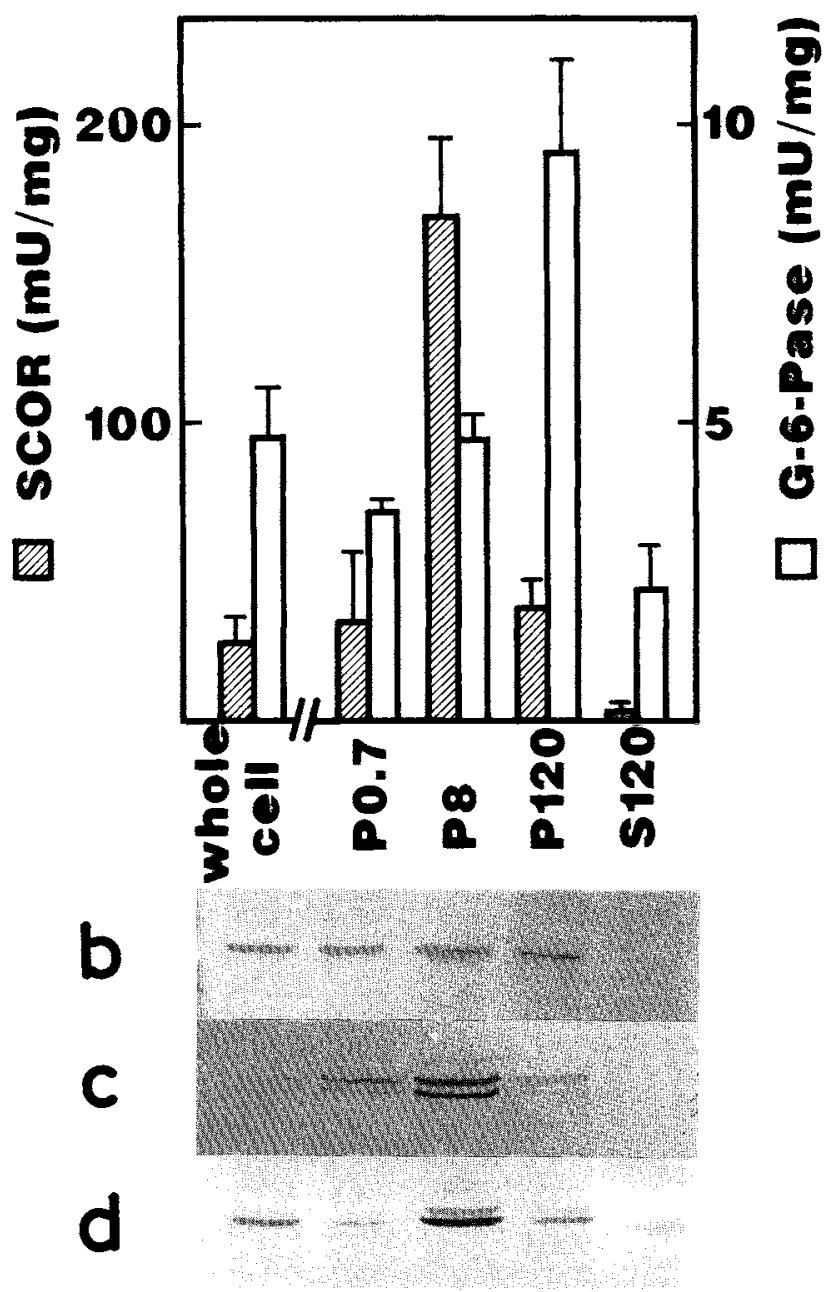

Fig. 3. Subcellular localization of expressed P-450d and P-450 (SCC). Transfected cells were homogenized and fractionated into four fractions (P0.7, P8, P120, S120) as described in Methods. Each fraction was used for marker enzyme activity assay and for immunoblotting. a. The cross-hatched bars show the mean values \pm S.D. (standard deviation) of observed succinate cytochrome c oxido-reductase activities (SCOR) as a mitochondrial marker. The blank bars show the values of glucose 6-phosphatase activities (G-6-Pase) as a microsome marker. Each datum is the arithmetic mean of duplicate or triplicate determinations. As indicated, the purification calculated from the increment of each marker activity is much higher for mitochondria than for microsomes ( 7 fold for mitochondria at P8, but 2 fold for microsomes at P120), suggesting a difference in protein content between microsomes and mitochondria in COS-7 cells. b. Immunoblotting of subcellular fractions from pKCRP-450d transfected COS-7 cells. The fraction for each lane contains $20 \mu \mathrm{g}$ of protein. c. Immunoblotting of the fractions from pKCRP-450 (SCC) transfected COS-7 cells. d. The same samples as c were subjected to proteinase $\mathrm{K}(70 \mu \mathrm{g} / \mathrm{ml})$ digestion for $120 \mathrm{~min}$ at $15^{\circ} \mathrm{C}$, then analyzed by immunoblotting. at $448 \mathrm{~nm}$ in microsomes (d-COS Ms) from cells transfected with the P-450d vector. From the height of the peak above the interpolated base line, the amount of expressed P-450d protein was estimated to be $0.49 \%$ of the total microsomal protein, consistent with the value of $0.2 \%$ estimated from the immunoblot analyses in Figs. $1 \mathrm{~b}$ and 3 . Positive peaks around $420 \mathrm{~nm}$ were also observed with both the d-COS Ms and H2-COS Ms samples. Freeze-thaw treatment of the d-COS Ms sample did not affect the ratio of the heights of the peaks at $448 \mathrm{~nm}$ and $420 \mathrm{~nm}$; the stability of the peaks suggests that the protein of the $420 \mathrm{~nm}$ peak did not originate from a denatured form of P-450 during the experimental processes. The nature of this background chromophore remains unknown.

$\mathrm{CO}$ difference spectra were also measured for mitochondria of cells transfected with the P-450(SCC) expression vector. The expected peak around $450 \mathrm{~nm}$ could not be detected due to background interference.

Table 1 summarizes the measured catalytic activities of expressed P-450d and P-450(SCC). The assays of P-

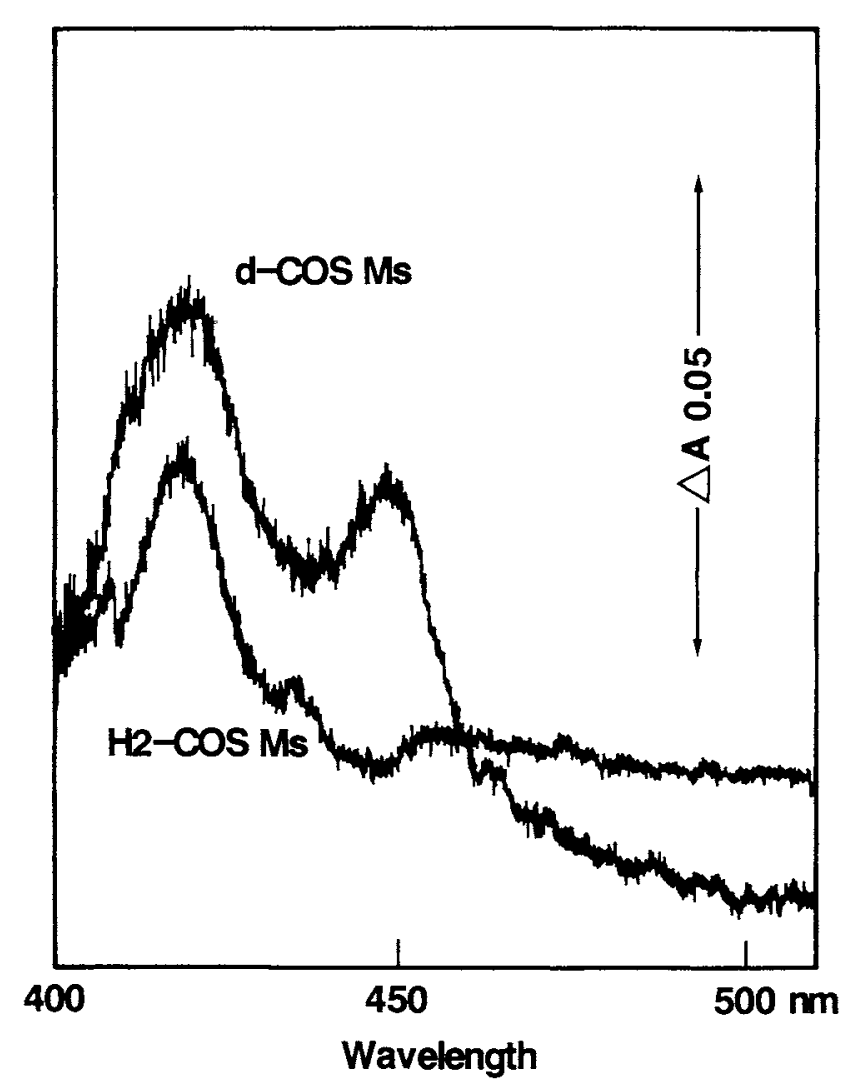

Fig. 4. Low temperature CO-reduced difference spectrum of microsomes from pKCRP-450d transfected cells. The spectra were recorded as described in Methods. Microsomes from pKCRP-450d transfected COS-7 cells (d-COS Ms) and from pKCRH2 transfected cells ( $\mathrm{H} 2-$ COS Ms) were used. 
$450 \mathrm{~d}$ activity were performed with estradiol-17, which is known to be one of the best substrates for P-450d.

The activity of Esd 2-hydroxylase in microsomes of the transfected cells was lower than that expected from the results of immunoblotting and $\mathrm{CO}$ difference spectroscopy. From the activity of $2.34 \mathrm{pmol} \cdot \mathrm{mg}^{-1} \cdot \mathrm{min}^{-1}$ in the microsomes, the amount of active P-450d enzyme is estimated to be $0.17 \mathrm{pmol} / \mathrm{mg}$, two orders of magnitude smaller than that calculated from the results of the immunoblotting. When assayed after the d-COS microsomes were reconstructed with $\mathrm{P}-450$ reductase $(\mathrm{Fp}$, $1: 10 \mathrm{~mol} / \mathrm{mol}$ ), the measured hydroxylase activity increased remarkably to a full activity of $211.8 \mathrm{pmol}$. $\mathrm{min}^{-1} \cdot \mathrm{mg}^{-1}$, from which the P-450d content was calculated to be $15.3 \mathrm{pmol} / \mathrm{mg}$ on the assumption that the turnover rate of pure $\mathrm{P}-450 \mathrm{~d}$ is $13.8 \mathrm{~min}^{-1}$. This value corresponds to $0.08 \%$ of the microsomal total protein. Since the reconstruction procedure usually yielded

Table I. Catabolic activity of expressed p-450.

\begin{tabular}{|c|c|}
\hline \multicolumn{2}{|c|}{$\begin{array}{l}\text { A. Effect of P-450 Reductase (Fp) Incorporation on Catalytic } \\
\text { Activity of Expressed P-450d }\end{array}$} \\
\hline & $\begin{array}{l}\text { Esd 2-hydroxylase Activity } \\
\text { (pmol/mg/min) }\end{array}$ \\
\hline $\mathrm{H} 2$ & $0.04>d$ \\
\hline d & 2.34 \\
\hline$d+F p$ & 8.20 \\
\hline$d+F p(R C)$ & 211.8 \\
\hline
\end{tabular}

B. Pregnenolone Production by COS-7 Cells Transfected

\begin{tabular}{lcc}
\multicolumn{3}{c}{ with P-450 (SCC)-cDNA } \\
\hline & cpm bound $^{\text {b }}$ & $\begin{array}{c}\text { Cold PRG added } \\
(\mathrm{pmol} / \mathrm{ml})\end{array}$ \\
\hline $\mathrm{CT} 0$ & 5370 & 0 \\
$\mathrm{CT} 2$ & 4200 & 2 \\
$\mathrm{CT} 5$ & 3850 & 5 \\
& & PRG formed \\
$\mathrm{H} 2+250 \mathrm{H}-\mathrm{CHL}$ & 5940 & $0.1>$ \\
$\mathrm{SCC}$ & 5520 & $0.1>$ \\
$\mathrm{SCC}+250 \mathrm{H}-\mathrm{CHL}$ & 4150 & 2.1 \\
\hline
\end{tabular}

${ }^{a}$ Estradiol 2-hydroxylase activity of microsomal fraction was measured. Averages of two independent determinations are shown. " $\mathrm{RC}$ " indicates reconstructed samples.

${ }^{b}$ By means of competitive binding of hot pregneolone with cold pregnenolone to be estimated, RIA was performed as described in Methods. Radioactivities of $\left[7-{ }^{3} \mathrm{H}\right]$-pregnenolone bound to the specific antibody are indicated. In the control experiments (CTOCT5), the indicated amount of cold pregnenolone was added to $1.0 \mathrm{ml}$ of fresh medium, which was then extracted, purified by HPLC, and applied to RIA. The epm values of control experiment are averages of four determinations. Those of the experiments with transfected cells are averages of two or three $(\mathrm{SCC}+250 \mathrm{H}-\mathrm{CHL})$.

c Values were obtained from the standard curve of the control experiment shown above (CT0-CT5). COS-7 cells were transfected and incubated for $120 \mathrm{~h}$ as indicated. The pregnenolone produced in $1.0 \mathrm{ml}$ of the medium was determined.

d $x>$, less than $x$. about $56 \%$ recovery (33), we concluded that almost all of the expressed P-450d protein was active enzyme, but was limited in interaction with the reductase.

The activity of expressed P-450(SCC) is also shown in Table 1B. It was, however, extremely limited; at least $100 \mathrm{~h}$ of incubation of the cells transfected with P-450 (SCC) CDNA was required for detection of the product. Intracellular cholesterol or a large amount of serum cholesterol contained in the culture medium did not seem to be availabel to the enzyme, whereas exogenous 25 hydroxycholesterol was utilized as a substrate.

\section{DISCUSSION}

In addition to $E$. coli (29) and yeast $(5,30)$, the COS cell, a cultured mammalian cell, provides a useful system for producing protein products from cloned cDNAs or genomic DNAs $(4,31)$. Since all eukaryotic $\mathrm{P}-450$ s are microsomal or mitochondrial proteins and need an electron transport pathway for their activities, the host cells used for the expression of these proteins may have to have such intracellular compartments for the stability and activity of the expressed proteins. These requirements are considered to be fulfilled in the COS cell.

In the present report we have demonstrated that two types of P-450, P-450d and P450(SCC), which were expressed in COS-7 cells were correctly sorted out and localized in their normal intracellular compartments. The expression of P-450 cDNAs in mammalian cell cultures has also been reported recently by other laboratories (32-34) with essentially the same results. Both types of P450 functioned as oxygenase, indicating the existence of electron transport chains within microsomes and mitochondria in COS-7 cells, although the electron supply seemed to be limited.

As shown in Fig. 3, the full length cDNAs of P-450d and $\mathrm{P}-450$ (SCC) did carry the information for their intracellular localization, which was functional even in the non-drug-metabolizing, non-steroidogenic COS-7 cells. While the mature form of expressed P-450(SCC) was located in the mitochondrial compartment, its precursor was found in all membranous fractions (Fig. 3). The relative amount of precursor among the membrane fractions varied form preparation to preparation. It is known that many eukaryotic mitochondrial proteins which are encoded by the nuclear genome are synthesized on cytoplasmic polysomes in precursor forms and then translocated into mitochondria to form mature proteins $(35,36)$. Accordingly, the cytosol may contain a pool of precursors for mitochondrial proteins which is in equilibrium between their continuous inflow and outflow (37). It is highly likely that most of the precursors found in the membrane fractions of the COS-7 cells (Fig. 3 ) originated from the cytosolic pool and that 
during the cell fractionation they attached aberrantly to the membrane fractions because of their lipophilic nature.

The time course of the precursor and the mature form of P-450(SCC) did not show a typical precursorproduct relationship (Fig. 2) and may suggest that through translocation of steroidogenic $\mathrm{P}-450(\mathrm{SCC})$ to mitochondria is somehow hindered in the COS cells either due to uncontrolled synthesis of the protein from the transfected expression vector or to lack of some specific factor for translocation.

All of the P-450d polypeptide obtained in the present expression system appears to be active enzyme with the same properties as the enzyme naturally occurring in rat hepatocytes (Fig. 4, Table 1). The same situation could hold true for P-450(SCC), although the heme incorporation could not be ascertained due to the high background noise in the $\mathrm{CO}$ difference spectrum. As shown in Fig. 3, P-450(SCC) precursor is correctly processed and transported to the mitochondrial inner membrane. Since there must exist abundant, newly synthesized protoheme in the matrix space, it seems probable that all the P-450(SCC) could incorporate the protoheme moiety to acquire enzymatic activity. Needless to say, however, one cannot ignore the possibility that the incorporation of protoheme into the apoprotein of $\mathrm{P}-450(\mathrm{SCC})$ is somehow inhibited in this expression system.

The rate of reactions catalyzed by the expressed P$450 \mathrm{~d}$ is limited by the amount of coupled NADPH-cytochrome P-450-reductase ( $\mathrm{Fp}$ ) in microsomes. The observation that the addition of purified Fp protein to microsomes and the subsequent reconstruction was sufficient to achieve efficient coupling of P-450d to the NADPHFp electron transport chain suggests that co-transfection with the expression vectors of P-450d and Fp might be a more convenient procedure. It has been reported that two microsomal P-450s, P-450 $17 \alpha$ (34) and P-450 (C21) (4), from steroidogenic cells were active enough to permit detection of their products in culture medium within several hours without supplying any of the reductase when COS cells were transfected with an expression plasmid conaining the respective cDNAs. Although the activities of these P-450s could be increased by supplementing with $\mathrm{Fp}$, these observations suggest that the intrinsic Fp of COS cells is sufficient to allow detection of the enzymic activity if substrate accessibility and product stability are ensured.

The COS-7 cells harboring the expressed P-450(SCC) were found to convert exogenous 25-hydroxycholesterol into pregnenolone, whereas endogenous cholesterol or that of the medium seemed hardly to be available to P-450(SCC), as already described (33) (Table 1). Such a preference of substrates is consistent with the hyopothesis that COS cell mitochondria lack the postulated "substrate translocator" (38) which would exist in steroidogenic mitochondria. Other lines of evidence suggest that the mitochondrial membrane lipids themselves might be a significant factor in activation of P-450(SCC) (39). Moreover, a recent report has demonstrated that certain peptide factors may activate the mitochondrial steroidogenic system in rat Leydig cells (40). Non-steroidogenic cells like COS cells may lack these components supporting the steroidogenic system.

In spite of some limitations in practical use, we have proved that the COS cell expression system is useful for production and characterization of cloned P-450 cDNA and genomic DNA (data not shown). Our laboratory has already successfully applied this system to analysis of causative mutations in defective P-450 genes of the inherited P-450 C21-deficient desease (4).

Acknowledgements. It is a pleasure for one of us (O. M.) to acknowledge the help of Professors H. Shiokawa and K. Yagi (Hokkaido University), who provided the opportunity to pursue this study. We would also like to express our gratitude to Drs. T. Tanaka, H. Shimada, and Y. Ishimura (Keio University) for the low temperature spectroscopy. Our sincere gratitude is due to Drs. T. Omura (Kyushu University) and K. Kawajiri (Saitama Cancer Center Research Institute) for antibodies against $\mathrm{P}-450(\mathrm{SCC})$ and $\mathrm{P}-450 \mathrm{c}$, respectively, and to Drs. M. Kusunose, E. Kusunose (Osaka City University), T. Komiya (Cancer Institute), and T. Iyanagi (Tsukuba University) for valuable technical advice on immunoblot analysis. We are grateful to Drs. K. Suhara and M. Katagiri (Kanazawa University) for valuable suggestions about the assay of P-450(SCC) activity, and to Drs. N. Yokotani, Y. Nabeshima, A. Fujisawa-Sehara, and H. Inoue (Cancer Institute) for their valuable suggestions and encouragement.

This work was partly supported by grants-in-aid for scientific research from the Ministry of Education, Science and Culture of Japan, research grants from the Japanese Ministry of Health and Welfare of Japan, and funds obtained under the Life Science Project from the Institute of Physical and Chemical Research, Japan.

\section{REFERENCES}

1. Gotoh, O. and Fujil-Kuriyama, Y. (1989). Evolution, Structure, and Gene Regulation of Cytochrome p-450. In Frontier in Biotransformation (K. Ruckpaul and H. Rein eds.). AkademieVerlag, Berlin, pp. 195-245.

2. Ortiz de Montellano, P.R., Ed. (1986). Cytochrome P-450, Structure, Mechanism and Biochemistry, Plenum, New York.

3. AdESNIK, A. and ATCHISON, M. (1985). Genes for cytochrome P-450 and their regulation. CRC Crit. Rev. Biochem., 19: 247305.

4. Higashi, Y., Tanae, A., Inoue, H., Hiromasa, T., and FumKURIYAMA, Y. (1988). Aberrant Splicing and missense mutations cause steroid 21-hydroxylase [P-450 (C21)] deficiency in humans: Possible gene conversion products. Proc. Natl. Acad. Sci. USA. 85: 7486-7490.

5. Shimizu, T., Sogawa, K., Fuji-Kuriyama, Y., Takahashi, M., Ogoma, Y., and Hatano, M. (1986). Expression of cytochrome P-450d by Saccharomyces cerevisiae. FEBS Lett. 207: 217-221.

6. Mishina, M., Kurosaki, T., Tobimatsu, T., Morimoto, Y., 
Noda, M., Yamamoto, T., Terao, M., Lindstrom, J., TAKahashi, T., Kuno, M., and Numa, S. (1984). Expression of functional acltylcholine receptor from cloned cDNAs. Nature 307: 604-608.

7. GLUZMAN, Y. (1981). SV40-transformed simian cells support the replication of early SV40 mutants. Cell 23: 175-182.

8. Wigler, M., Sweet, R., Sim, G.K., Wold, B., Pellicer, A., Lacy, E., Maniatis, T., Silverstein, S., and Axel, R. (1979). Transformation of mammalian cells with genes from prokaryotes and eukaryotes. Cell 16: 777-785.

9. Luthman, H. and Magnusson, G. (1983). High efficiency polyoma DNA transfection of chloroquine treated cells. Nucleic Acids Res. 11: 1295-1308.

10. Chirgwin, J.M., Przybyla, A.E., MacDonald, R.J., and RUtTER, W.J. (1979). Isolation of biologically active ribonucleic acid from sources enriched in ribonuclease. Biochemistry 18: 5294-5299.

11. Kawajiri, K., Yonekawa, H., Gotoh, O., Watanabe, J., IGARASHI, S., and TAGASHIRA, Y. (1983). Contribution of two methylcholanthrene-inducible forms of cytochrome $\mathrm{P}-450$ in rat liver microsomes to the metabolic activation of various chemical carcinogens. Cancer Res. 43: 819-823.

12. BRADFORD, M.M. (1976). A rapid and sensitive method for quantitation of microgram quantities of protein utilizing the principle of protein-dye binding. Anal. Biochem. 72: 248-254.

13. LAFmmLi, U.K. (1970). Cleavage of structural proteins during the assembly of the head of bacteriophage $\mathrm{T}_{4}$. Nature 227: 680685.

14. Ryan, D.E., Thomas, P.E., and Levin, W. (1982). Purification and characterization of a minor form of hepatic microsomal cytochrome P-450 from rats treated with polychlorinated biphenyls. Arch. Biochem. Biophys. 216:272-288.

15. Suhara, K., Gomi, T., Sato, H., Itagaki, E., Takemori, S., and KATAGIRI, M. (1978). Purification and immunochemical characterization of the two adrenal cortex mitochondrial cytochrome P-450-proteins. Arch. Biochem. Biophys. 190: 290-299.

16. Aronson Jr., N.N. and Touster, O. (1974). Isolation of rat liver plasma membrane fragments in isotonic sucrose. In Methods in Enzymology vol. XXXI, (S. Fleischer and L. Packer, eds). Biomembranes part A, Academic Press, New York, pp 95-96.

17. Kearney, E.B. (1957). Studies on succenic dehydrogenase IV. Activation of the beef heart enzyme. J. Biol. Chem. 229: 363375.

18. Swanson, M.A. (1955). Glucose-6-phosphatase from liver. Methods in Enzymology vol. II., (S.P. Colowick and N.O. Kaplan, eds.). Academic Press, New York, pp 541-543.

19. FISKE, C.H. and Subbarow, Y. (1925). The colorimetric determination of phosphorus. J. Biol. Chem. 66: 375-400.

20. Ou, W., Ito, A., Morohashi, K., Fuji-Kuriyama, Y., and OMURA, T. (1986). Processing-independent in vitro translation of cytochrome P-450(SCC) across mitochondrial membranes. J. Biochem. 100: 1287-1296.

21. Klingenberg, M. (1958). Pigments of rat liver microsormes. Arch. Biochem. Biophys. 75: 376-386.

22. Hagrhara, B. and IIZUKA, T. (1971). Studies on low temperature spectra of respiratory pigments I. Measurement of absorption spectra between liquid helium and room temperature. $J$. Biochem. 69: 355-362.

23. IIZUKa, T., KanEGaSAKI, S., MaKino, R., TANAKA, T., and Ishimura, Y. (1985). Studies on neutrophil b-type cytochrome in situ by low temperature absorption spectroscopy. J. Biol. Chem. 260: 12049-12053.
24. Iyanagi, T., Makino, R., and Anan, F.K. (1981). Studies on the microsomal mixed-function oxidase system: Mechanism of action of hepatic NADPH-cytochrome P-450 reductase. Biochemistry 20: 1722-1730.

25. Miwa, G.T. and LU, A.Y.H. (1984). The association of cytochrome P-450 and NADPH-cytochrome P-450 reductase in phorpholipid membranes. Arch. Biochem. Biophys. 234: 161166.

26. Numazawa, M., Kryono, Y., and Nambara, T. (1980). A simple radiometric assay for estradiol 2-hydroxylase activity. Anal. Biochem. 104: 290-295.

27. Abraham, G.E., Buster, J.E., Kyle, F.W., Corrales, P.C., and TELLER, R.C. (1973). Radioimmunoassay of plasma pregnenolone. J. Clin. Endocrinol. Metab. 37: 40-45.

28. Reeves, R., Gorman, C.M., and Howard, B. (1985). Minichromosome assembly of non-integrated plasmid DNA transfected into mammalian cells. Nucleic Acids Res. 13: 3599-3615.

29. Talmadge, K., Brosius, J., and Gilbert, W. (1981). An internal signal sequence directs secretion and processing of proinsulin in bacteria. Nature 294: 176-178.

30. Hitzeman, R.A., Leung, D.W., Perry, L.J., Kohr, W.J., Levine, H.L., and Goeddel, L.D. (1983). Secretion of human interferon by yeast. Science 219: 620-625.

31. Higashi, Y., Sokawa, Y., Watanabe, Y., Kawade, Y., Ohno, S., TAKAOKA, C., and TANiguchi, T. (1983). Structure and expression of a cloned cDNA for mouse interferon $\beta . J$. Biol. Chem. 258: 9522-9529.

32. Battula, N., Sagara, J., and Gelboin, H.V. (1987). Expression of $P_{1}-450$ and $P_{3}-450$ DNA coding sequences as enzymatically active cytochromes P-450 in mammalian cells. Proc. Natl. Acad. Sci. USA. 84: 4073-4077.

33. Zuber, M.X., Mason, J.I., Simpson, E.R., and Waterman, M.R. (1988). Simultaneous transfection of COS-1 cells with mitochondrial and microsomal steroid hydroxylases: Incorporation of a steroidogenic pathway into nonsteroidogenic cells. Proc. Natl. Acad. Sci. USA 85: 699-703.

34. Zuber, M.X., Simpson, E.R., and Waterman, M.R. (1986). Expression of bovine 17- $\alpha$-hydroxylase cytochrome P-450 cDNA in nonsteroidogenic (COS 1) cells. Science 234: 12581261 .

35. Suissa, M. and Schatz, G. (1982). Import of proteins into mitochondria. Translatable mRNAs for imported mitochondrial proteins are present-in free as well as mitochondria-bound cytoplasmic ribosomes. J. Biol. Chem. 257: 13048-13055.

36. Nabi, N., Kominami, S., Takemori, S., and Omura, T, (1983). Contribution of cytoplasmic free and membranebound ribosomes to the synthesis of mitochondrial cytochrome P-450(SCC) and P-45011 $\beta$ and microsomal cytochrome P-450 (C21) in bovine adrenal cortex. J. Biochem. 94: 1517-1527.

37. REID, G.A. and SCHATZ, G. (1982). Import of proteins into mitochondria extramitochondrial pools and posttranslational import of mitochondrial protein precursor in vivo. J. Biol. Chem. 257: 13062-13067.

38. Lambeth, J.D., XU, X.X., and Glover, M. (1987). Cholesterol sulfate inhibits adrenal mitochondrial cholesterol side chain cleavage at a site distinct from cytochrome $\mathrm{P}-450$ (SCC). J. Biol. Chem. 262: 9181-9188.

39. IgARASHI, Y. and Kimura, T. (1986). Adrenic acid content in rat adrenal mitochondrial phophatidylethanolamine and its relation to ACTH-mediated stimulation of cholesterol side chain cleavage reaction. J. Biol. Chem. 261: 14118-14124.

40. Pedersen, R.C., and BrownIe, A.C. (1987). Steroidogenesisactivator polypeptide isolated from a rat Leydig cell tumor. 
O. Minowa, et al.

Science 236: 188-190.
(Received for publication, August 31, 1989 and in revised form, October 18,1989 ) 